The Open Psychology Journal
Bentham OPen
CrossMark
DOI: $10.2174 / 1874350101710010182$

RESEARCH ARTICLE

\title{
A Peace Pedagogy Model for the Development of Peace Culture in An Education Setting
}

\author{
Riswanda Setiadi ${ }^{1}$, Sunaryo Kartadinata ${ }^{2, *}$, Ilfiandra $^{2}$ and Ayami Nakaya ${ }^{3}$ \\ ${ }^{I}$ Department of French Language Education, Faculty of Language and Literature Education, Universitas Pendidikan \\ Indonesia, Kota Bandung, Indonesia \\ ${ }^{2}$ Program of Guidance and Counseling, Department of Educational Psychology and Guidance, Faculty of Education, \\ Universitas Pendidikan Indonesia, Kota Bandung, Indonesia \\ ${ }^{3}$ Hiroshima University, Hiroshima, Japan
}

Received: June 21, 2017

Revised: July 24, 2017

Accepted: September 22, 2017

\begin{abstract}
:
Introduction:

In today's global situation, the issue of living together in peace and harmony is increasingly crucial and has become a challenge for all, including the education sector.

Aims:

In this regard and because of the need to develop a harmonious and peaceful world, the present study aimed at constructing a peace pedagogy model which could foster a culture of peace in any educational institution. To elaborate, we describe the implementation process of a peace model in a school environment. For appropriateness, a qualitative approach with a case study method was used. 35 students were taken as the participants of the study, chosen from the eleventh grade of the science class of Universitas Pendidikan Indonesia's demonstration High School, plus 7 teachers were taken from Indonesian Language, History, Civic Education, Islamic Education, Arts, Guidance and Counseling, and Biology departments. All the participants were purposively selected as informants to the study.
\end{abstract}

\section{Conclusion:}

The model was demonstrated in 14 class sessions of 40 minutes each spread across the seven mentioned school subjects. Data were analysed thematically and triangulated based on theoretical comparison and personal reflection. Conclusively, it was etablished that the model's implementation had no significant effect on the creation of a safe and peaceful classroom environment based on the zone of peace parameters. It was finally revealed that their weaknesses regarding the model's construction, teachers' knowledge about the model, differences in teachers' abilities, challenges in classroom management and inadquate student support activities.

Keywords: Pedagogy, Peace, Culture, Safe and peaceful, Education, Institution.

\section{INTRODUCTION}

In today's global situation, the issue of living together in peace and harmony is increasingly crucial and has become a challenge for all, including the education sector. Many approaches, methods and models have been put in place to encourage learners develop the necessary knowledge and skills required to prevent and solve conflicts as responsible citizens. Because studies have revealed that anger and juvenile violence are among the common issues faced by teachers and school psychologists [1]. Education institutions are now being considered as places that can improve or

\footnotetext{
* Address correspondence to this author at the Program of Study of Guidance and Counseling, Department of Educational Psychology and Guidance, Faculty of Education, Universitas Pendidikan Indonesia, Kota Bandung, Indonesia; Tel: +62811214047; E-mail: skartadinata@yahoo.com
} 
worsen a community's peace situation because a school is the most appropriate channel or vechile that can foster the development of a peaceful and or harmonious society. It is believed that through peace pedagogy violent acts can diminish from our communities which have been known for quit a long time to be emerging from local communities (i.e., conflicts) [2]. Hence, it has not been difficult to find fights, bullying, and conflicts among adolescents [3] within the local communities and also now in our schools and course classrooms.

Jacques Delors the Chief of International Commisions on Education for the Twenty-first Century presents a similar idea in a UNESCO report of 2006 of " learning to live together, learning to live with others. This type of learning is probably one of the major issues in education today because education institutions receive people from the different backgrounds, who are then entrusted to teachers as custodian, being forced to deal with the varying and direct effects of anger and aggression such as violent threats and conflicts among learners, but also indirect effects such as learning difficulties and personal adjustment [1].

The long-term strategic plan of Indonesia is to encourage long-term "peace education" and "global education", namely, peace education that is expected to help solve global problems. The most significant strategy to promote a culture of peace is through peace education [4]. Peace education (education for peace) aims to develop learning that support social cohesion, justice, and the preservation of the environment according to Salomon and Nevo, 2002, and Wenden, 2004, in [5]. Education in general and schooling in particular play an important role in creating "structural violence", namely, the unbalanced and oppressive socialeconomic and political relations according to Galtung in [6]. In practice, peace education has five characteristics: transformative, process-centered, participatory, relational and sustainable [7].

In the Indonesian education system, from kindergarten to university level, there is no program or educational services that explicitly develops values of peace. In the context of conflict it is suggested [8], that " there is no doubt of the real need for a comprehensive conflict resolution programs in the school". A more assertive statement can be found [9] that "a comprehensive conflict resolution program promotes a safe school environment that permits optimal personal growth and learning". It has been recommended [10] that schools should plan, implement and evaluate peace curriculum. Learners are given knowledge about personal development, social skills, as well as feeling peace with themselves in the school environment, family and community. Based on these considerations, the existence of educational models that can foster a culture of peace in schools is a necessity.

Up to now, the development of peace pedagogy does not yet have a solid platform and basis as it is still in the pilot stage despite the everday practice of those values in education. The local wisdom values should be re-examined and developed as social capital within the framework of creating a peaceful life that is characterized by the presence of harmony with ourselves, with others and the environment. The results of the first year research have formulated a model of peace pedagogy to build a culture of peace in formal education. This model was built through the integration of theoretical studies about the peace education program models that have been implemented in developed countries in Europe and Asia, with the focus on empirical studies related to the culture of peace in the school and community. The research problem is whether the model of pedagogy of peace has a high feasibility to be implemented to develop peace culture in formal education.

In general, this study aims to construct a model of peace pedagogy in order to foster a culture of peace at formal education level. It is intended to assess the feasibility of the model and introduce it to the educational stakeholders at school level in order to develop a support system for its holistic model implementation.

\section{LITERATURE REVIEW}

Everyone needs peace, as they need happiness, justice, and prosperity. From time to time, the need for a culture of peace and peace itself is very urgent. In this case, it is revealed [4] that, " no time is more appropriate than now to build a culture of peace. No social responsibility is greater nor task heaver than that of securing peace on our planet on a sustainable foundation ". To live together in peace and harmony is also a challenge, for educators, while students themselves also faced with the challenge in their personal lives. The report of the International Commission on Education for the twenty-first century, or better known as the Delors Report has identified seven issues that threaten humanity with direct implication on the values, namely: the conflict between the global-local, universal-individual, traditional-modern, short-term and the long term consideration, competition-cooperation, expansion of knowledge expansion-assimilation skill, and the spiritual-material.

The Commission recommends the reconceptualization of education based on the principle of lifelong learning that is 
supported by four pillars: learning to know, learning to do, learning to be and learning to live together. Perhaps this suggestion is based on the historical fact that education does not automatically bring a message of peace, democracy, and respect for the rights and welfare of others [11] revealed that " education can be part of the problem as well as part of the solution. Policies and practices at all levels within the education system need to be analyzed in terms of their potential to aggravate or ameliorate conflict". On this basis, the peace education is an important solution in creating an ideal atmosphere for human life.

Peace education is not limited to conflicts and solves them peacefully, and will be more effective if adapted to the social context, culture, needs and aspirations of a country. Peace education needs to be strengthened by the values of culture, religion, and humanity values and can even be regarded as the "essence of a new humanity". The definition of a culture of peace based on the Declaration on a Culture of Peace in 1999 is " as a set of values, attitudes, traditions, modes of behavior and ways of life based on respect for life". A culture of peace cultivates a mindset characterized by the transition from the use of force to the reasoning, of conflict and violence to dialogue and peace.

In the context of peace pedagogy, there are some principles that should be addressed: (1) peace education is not a proper school subject. Peace is not just an end, but it must be presented as the climate, a climate that covers instructional interactions; (2) peace education is a conscious effort of all parties to change the ways of solving problems that do not jeopardize the social order and justice; (3) how a good human life is identified in culture. It could refer to the definition of religion, law, or rule or anything considered functional. As with any culture that has universal elements, but is often present contextually, the way humans translate and teach peace can refer to the universal and local standards; (4) the fundamental to peace education is teachers' commitment to shape the experiences and preferences of the students in order to promote peaceful means despite a variety of difficulties faced by them.

Finally, peace can be made when the entire population of the world is aware of and understands the world's problems globally, has conflict resolution skills, and strives to uphold justice without violence, living with reference to the standards of human rights and equity, appreciate cultural diversity, mutual respect between fellow citizens. All this can be achieved through systematic peace education according to Solomon [12]. In relation to the model of peace education, there are various terms among others, such as Conflict Resolution Education (CRE), peace education, peacemaking, violance prevention or violance reduction [9]. Models of conflict resolution have some things in common, namely, to develop students to be able to realize that conflict is a part of life and capable of solving it peacefully, develop awareness of the uniqueness of individual response to conflict and understand the differences in the response of others, learn to practice the principles and skills of conflict resolution and empowering students to be able to be responsible to jointly resolve conflicts peacefully and to integrate this responsibility in daily life.

Many studies have been carried out to identify the effects of conflict resolution education. A study [13] found that conflict resolution and peer mediation training can improve academic achievement. Conflict resolution education in US schools has a positive impact on students, schools, and communities [14]. Research [15] found that conflict resolution can improve students' skills in problem solving, critical thinking, decision making, and improve social skills, such as respect for diversity, empathy, cooperation, exploration and expression of feelings. Another study [16] also supports the positive impact of conflict resolution education, which improves problem solving skills and adolescent self-concept. Adolescents in the study showed significant improvement in self-concept, both physically and affectively. It is proved [16] that peer mediation reduces conflict and increases the tendency to help others in conflict, increase prosocial values, improve the ability to understand another person's perspective, and reduces aggressiveness.

\section{METHODOLOGY}

This study adopts a qualitative approach to describe the efforts of school subject teachers in implementing the model of peacepedagogy as the main parameter. The method used was a case study with analysis unit analysis of the the implemention process of the peace pedagogy model to build safe and peaceful classrooms.

\subsection{Subjects}

The research subjects in this study were seven high school teachers of UPI Laboratory School (demonstration school) who teach Islamic Religious Education, History, Civics Education, Biology, Indonesian language, Arts and Counseling and Guidance. Focus was on the implementation of the intervention model of peace pedagogy in building a culture of peace in schools that were integrated in the teaching subjects and the counseling and guidance services. The other research subjects were 35 eleventh grade students who were selected purposively. 


\subsection{Data Collecting Instruments}

This research is classified into a general qualitative procedure to reveal data on narrative and descriptive basis. The research instrument is the observation sheet of zone of peace developed [4]. To complement the research data, an interview was conducted to reveal teachers' experiences with the model's implementation.

\subsection{Data Analysis and Interpretation}

Qualitative data collected through interviews and observations are presented in a narrative, logically analyzed, reflected on and interpreted by the researchers as well as any other relevant literature. To arrive at the final conclusion, the data were adjusted to the best practices of peace education in order to avoid subjectivity in obtaining final results.

\section{FINDINGS AND DISCUSSION}

Based on observations during the implementation of the model and the results of interviews with teachers, a temporary conclusion can be drawn that the integrated implementation of the peace pedagogy model in these subjects and guidance and counseling has not worked as planned. For example, in the biology class discussing about "the circulatory system" fully explains the substance of the subject, despite the fact that there is little room to incorporate issues of peace when discussing the impact of unbalanced blood cells of the body. The atmosphere during the hectic learning even tends to fuss, so many times the teacher had to say, 'listen to this first' in an attempt to create a conducive atmosphere. The cozy atmosphere did not last long as students return to divided attention, chatting with friends, dozing, even doing things that are not related to the subject. Noisy classroom was always uncontrolable, respectful behavior only materialized when the teacher complements a student after a student posed an idea. Ironical phrases such as "you're noisy" during the learning activity were used and quite often taken as a joke by the students.

The implementation of the model in the counseling and guidance services was done by discussing the topic of 'cooperation and tolerance' and 'problem solving'. Experiential efforts were made by the teacher through games like 'Matches Tower'. After going through the preliminary stages of group formation, the students formed a 'tower of matches' within 10 minutes. Once the game was over, there was no elaboration or counsel on the moral and values of the game, especially those associated with building a safe and peaceful class. On the topic of 'finishing', at one stage the teacher was to provide students with worksheets that contain conflict situations faced by students. In groups, the students were encouraged to find alternative solutions to conflict situations. At the end of each session, group representatives present the results of their analysis. Just like the previous session, the supervising teacher was not able to explain the essence of the conflict faced by students and how best to look for alternative solutions. The apparent weaknesses can be seen in the teacher's effort to generalize and infer group activities in relation to peace issues in the context of the students' daily life. The model in the Indonesian language class was implemented by discussion in the topic of 'writing rhymes'. Typical of the Indonesian class, the teacher began by greeting, checking the student attendance and saying, 'be quiet, ok". The lesson began with playing a video about the poem, during the activity, the atmosphere was noisy, students talked to each other, students occupied with a flurry of their own, some even commented about video. There was also a female student who touched the arm and head of a boy and pushed it saying 'why'. After students finished writing rhymes in groups, each group performed in front of the class by reading their rhyme. During the presentation, the other students were noisy, engaged in other activities while occasionally laughing and commenting, 'it's funny...'. The teacher responded to the students' comments by saying 'be quiet, listen!'. The lesson closed with a question by the teacher whether the poem was written by a fine and virtuous friend. Just like in other subjects, the teacher does not draw inferences of the subject to building a safe and peaceful classroom climate. In the Arts and Culture class, the model was not implemented in accordance with the existing guidelines. However, there were a few things noted about the learning activities in this class. First, the class was managed in a form of cooperative learning where students work in groups to complete the tasks assigned by the teacher. Second, students showed enthusiasm to accomplish their tasks even though the task completion was spontaneous. Third, occasionally teachers helped students complete their assignments in the form of song creation. Fourth, there was no action or activity that specifically led to the cultivation of attitudes or values of peace, but there were only a few keywords related to attitudes and values, like appreciation and respect. Both of these keywords are already important components in the process of learning art and culture. The History class was managed in a classical process. At the time of observation, the lesson being taught was about the period of the establishment of independence fighting organizations. Teachers simply asked students to work together to find information about when and where those organizations and movements were established. Cooperation became an important feature in this class but there was no process or activity that showed how 
the values of peace were applied in the classroom. Overall, this class was not able to implement a model of peace with good pedagogy. In this case, the teacher was not ready to apply the model.

In general, the results of the model show that the safe and peaceful classroom climate as an ultimate goal was not created. There are many perspectives to explain these findings, among others, from the substance of the model, the readiness of the teacher and student to participate. From the technical side of research, the implementation of 14 classroom sessions is not a guarantee for changes in the climate. In terms of teachers, their understanding of the model, classroom management skills, and role model in pedagogy of peace are among the obstacles. The next discussion focuses more on the substance of the peace pedagogy and normative role of teachers in the context of peace pedagogy.

Peace education program at school level is basically a character development intervention based on human values, moral, and spiritual laws that put an emphasis on developing competencies and peaceful life of the students [17]. The peace education program extends from the individual, school, state to the global level. At the individual level, to be able to live peacefully the students require a lot of skills, such as affirmative acts, positive thinking, empathetic listening, assertive behavior, decision making skills. Peace at school level focuses on the development of the climate or the spirit of peace through the slogan 'has to be caught rather than be thought' that begins from the inside with a spirit of appreciation, cooperation, and learning to trust each other. Relationships built on the spirit of brotherhood and respect will naturally give birth to peace in schools supported by the system of values, norms that guide everyday behavior of students in school [17].

Peace is the ideal state in international relations, inter-group relations between ethnic groups,interpersonal relationships (family and work) and intrapersonal peace for psychological and spiritual purposes. Peace in the whole relationships is important for human health and welfare. The review of several studies conclude that the welfare and psychological health would be realized if the relational aspect in various levels are integrated harmoniously [18]. Harmonious interpersonal relationships are related to health and happiness [19]. The attitude of people in large groups affect each other whether the state encourages war or promotes peace.

Peace is defined as a condition of the individual, family, community or country that has low and high levels of violence in harmony of mutual and beneficial relationship [20]. The context of the peace according to Anderson is within the individual (intrapersonal peace), individuals (interpersonal peace), between social groups (social peace), in the community (civil peace), in the state (national peace), inter-state (international peace) and with nature (natural peace), and with the ultimate reality or God (existential peace). In the context of the theory about the level of peace developed [4], four characteristics that represent Sundanese personality can be categorized as personal peace that is characterized by the values of self-respect, inner resources, love, and hope.

The school has a strategic position as an agent of peace and cultural development, and teachers are a central figure, but the school principal's support is still limited. Therefore special efforts are required [21]. Teacher-centered approaches and subjects are not effective for peace education. Unlike the subjects, peace education depends on teachers' personality. Students learn the peaceful behavior of how the teacher speaks, responds to the challenge and look at certain issues than what the teacher taught. Teachers who are not peaceful cannot teach peace as their behavior is contrary to what they teach [17] so it is not excessive if the pedagogy of peace is an "honorable" potential for respect for human rights [21]. Teenagers are the main capital in building a culture of peace. Therefore, teenagers are more likely to avoid violence and may be involved in instilling a culture of peace if given an opportunity to mutually bound and strengthening in instilling a culture of peace in a common life [22].

Peace pedagogy to develop a culture of peace focuses on the development of mindset instead of micro competence. It departs from the statement "since war begins in the minds of men, it is in the minds of men that defenses of peace must be constructed" [17]. The values of peace as local wisdom certainly do not appear immediately, but proceed so long that eventually proved to contain a favor for life. In this case, local knowledge in a tradition and culture is strongly attached to people's lives. That is, to a certain extent there are perennial values that are deeply rooted in every aspect of cultural locality.

The peace spectra targeted by this model is holistic because it has vertical (transcendent) and horizontal (instrapersonal and interpersonal) dimensions. This is in fact the essence of education itself as a learning process that is based on the formulation of philosophical values that every individual is able to understand the values of truth and universal truth. Through education, each person must not only be good for itself, but should benefit the wider society and be able to establish a good relationship with God the Creator. In this context, learning outcomes are evaluated to brush up knowledge and behavior that is not fully in accordance with the nature of the values of truth and goodness of 
life which are universally recognized [23].

Today the children should be educated about the art of living peacefully and harmoniously and social cohesion as practical values. Everybody is aware that the excessive emphasis on cognitive learning led to disturbance to the development of emotional, social, moral and humanistic aspects [4]. Education is failing to equip people with the ability to live in peace instead of actual meaningful education. In fact, almost all topics in the curriculum have been designed to steer students on a peaceful and happy life, but the process of learning about peace and happiness in the classroom is seemingly unreal [24].

There is a fundamental question whether education uses or generates value. It is a 'deliberate process' that is socially acceptable and for social purposes. Education then becomes the value loaded because the entire human process involves the actual value and it is in fact an educational process, because educational and cultural ties cannot be separated. There is no culture without education and so are the educational praxis always in the cultural sphere. In that context, education has a deliberative meaning, that "every society tries to transmit the fundamental ideas regarding the nature of the world, knowledge, and values they adhere to" [25].

Peace education needs to be introduced to children as early as possible, in different methods. Teaching the values of tolerance, understanding, and respect for diversity can be introduced through their exposure to many different countries, geography, history and culture as an empowering them to become agents of peace in the context of their environment [4]. The power of understanding and perspective on peace as conditions and values cannot be overemphasized. For this reason it is confirmed that the need for a change of mind about the concepts and values as a first step to solve today's issues [4].

Peace education is fundamental, and it is not only about the results but the process as well [26]. It is a process of not merely learning about peace and war, but requiring knowledge about peace and war, and involves learning to live peacefully as citizens in a democratic society Development of resources to help educators and administrators to implement peace education is an important step in developing a culture of peace [26]. In relation to the content of peace pedagogy, the educational contents can be knowledge and skills of everyday events that occur in the classroom, that can turn the students into agents of peace in their life [21].

In many classes, teachers mostlyadopt the approach of "learning about" or "learning to". "Learning about" approach stresses knowledge with a focus on assimilation and interpretation of facts, concepts, data, and facts. The "learning to" approach focuses on the acquisition of values and the development of skills that allow the learners to apply what they have learned. "Learning in or through" approach is the actual process of learning which is considered to be relevant to peace education [27]. And the knowledge and skills necessary to live in peace are reinforced by a reflection during the learning process, after learning and for the long-term behavior [21].

The learning process begins with the development of internal peace in the mind and heart of individuals who seek the truth, knowledge and understanding of their respective cultures and respect for shared values to achieve a better future. Those who have internal peace are identified as having dignity and recognition as social beings [4]. Learning to live together in peace requires the quality of relationships at all levels, is a commitment to peace, human rights, democracy and social justice in an environment that is ecologically balanced.

In relation to the research questions and the model's implementation procedures, the main basis for peace education is [28] a statement that peace education should "... constitute a very real part of the day to day 'incidental' learning that takes place in a classroom". Peace education is practical rather than theoretical as education is truly a project of awareness of the meaning of being human and interaction with nature and other creatures. This includes learning to care and care for the environment. In the context of the application of pedagogy, peace education is not a particular subject. It is not the end, but a climate that covers learning interaction [29]. This view is in line with a view that peace education involves the creation of "zone of peace" in a classroom, the school and the surrounding environment in the form of physical space, psychological and caring, safe and joyful learning [28].

\section{CONCLUSION}

The peace pedagogy model can be applied at structural and personal levels. Structurally, the vision and mission of peace are embbeded through peace education seminars involving all teachers and principals in the hope that a peaceful mindset is ingrained in the minds of all stakeholders of the school. Personally, the mindset of peace is disseminated through training activities and the model application in school subjects as well as guidance and counseling services. In general, the implementation of the model does not seriously affect the formation of a safe and peaceful classroom 
climate based on the parameters of the zone of peace. The model is still weak in some cases, mostly its constructs, teachers' understanding of the model, teachers' capacity building, teachers' classroom management skills, and students' support.

Based on the research findings and referring to educational theories and reviews, it is recommended that: (a) implementation of the peace pedagogy requires teachers to be creative and innovative. Therefore, teachers are expected to be willing to open themselves to learn a lot about peace pedagogy. The training and materials they learned and gained during capacity building activities are only one stimulus. They should further enrich their knowledge and skills on peace education. It aims to ensure the sustainable implementation of the model at the aftermath of the research. This perspective is in line with one of the principles in pedagogy of peace, which requires that the building of a culture of peace is a long process; (b) the culture of peace is not merely the personal affairs of school personnel, but rather a collective effort of education stakeholders. Thus the development of a culture of peace in schools needs systematic and systemic efforts in the constellation of interpsersonal interaction. At the level of the image, the peaceful spirit is attached to the school vision and mission so that it becomes the awareness of all elements of the school. Furthermore, for more elaborative, the values of peace culture become a part of the curriculum. To avoid exclusiveness and reduce academic burden, the peace pedagogy should be integrated into the existing school subjects. To be more comprehensive, the development of a culture of peace can also be attached to a variety of extracurricular programs. With a variety of modes, the development of a culture of peace in schools through interventions can be carried out through the structural organization, and simultaneously at the individual level, and (c) education for peace and the spirit of peace should be the mission of every teacher. During the implementation of the model, there was an uncertain interaction between the curriculum goal achievement on the one hand and the development of a safe and peaceful class climate on the other hand. The simple logic that teachers must hold is that when the class climate is safe and peaceful, the learning process will be more conducive as there is less interruption that damages learning atmosphere. Therefore, classroom management is a micro skill that should be urgently developed.

\section{ETHICS APPROVAL AND CONSENT TO PARTICIPATE}

Not applicable.

\section{HUMAN AND ANIMAL RIGHTS}

No Animals/Humans were used for studies that are base of this research.

\section{CONSENT FOR PUBLICATION}

Not applicable.

\section{CONFLICT OF INTEREST}

The authors declare no conflict of interest, financial or otherwise.

\section{ACKNOWLEDGEMENTS}

We would like to appreciate the Directorate General of Research and Social Services at the Indonesia's Ministry of Research and Higher Education for funding this research. We also wish to express our gratitude and thanks to Universitas Pendidikan Indonesia's Institute for Research and Community Services for facilitating this research. We cannot forget the entire rectorate of Universitas Pendidikan Indonesia for its encouragement and support regarding publication, especially Prof. Didi Sukyadi, MA, he is really doing a wonderful job. Finally, we really appreciate the school principal, deputy principal, teachers and senior high students of the Universitas Pendidikan Indonesia's Demonstration School for the assistance and cooperation during the study. We pray that God Bless each and every body in the different capacities!

\section{REFERENCES}

[1] Lochman JE, Powell NR, Clanton N, McElroy HK. Background and Development. SPONS AGENCY 1997 ; p. 149.

[2] Colombijn F, Lindblad JT, Eds. Roots of violence in Indonesia: contemporary violence in historical perspective. Brill Academic Pub 2002.

[3] Rais J. Planning sustainable land management at regional level: The Indonesian case. ITC J 1997; 3(4): $273-7$.

[4] Navorro-Castro L. Peace Educatgion. In: A pathway to a Culture of Peace. Mirieam College: Center of Peace Education. 2010 ; pp. 1-211. 
[5] Carter C, Vandeyar S. Peace education in conflict and post-conflict societies comparative perspectives 2009; $247-61$.

[6] Harber C, Sakade N. Schooling for violence and peace: How does peace education differ from 'normal'schooling? J Peace Educ 2009; 6(2): 171-87. [http://dx.doi.org/10.1080/17400200903086599]

[7] Deck SL. Transforming High School Students into Peace builders: A rationale for the Youth Initiative model of peace education. University of Sydney: Sydney 2010. CPACS Working Paper No. 12/1 September

[8] Garner NE. Conflict Resolution Programs in Schools Professional Counseling Digest. Austin, TX: American Counseling Association 2004.

[9] The American School Counselor Association (ASCA). National standards for school counseling programs. : Alexandria, VA: ASCA 2002.

[10] Lasser J, Adams K. The effects of war on children: School psychologists' role and function. Sch Psychol Int 2007; 28(1): 5-10. [http://dx.doi.org/10.1177/0143034307075669]

[11] Smith A, Vaux T. Education, conflict and international development. UK Department for International Development (DFID). 2003 ; 1-65.

[12] De Rivera J. Handbook on Building Cultures of Peace. New York: Springer 2009. [http://dx.doi.org/10.1007/978-0-387-09575-2]

[13] Johnson DW, Johnson RT. Conflict Resolution and Peer Mediation Program in Elementary and Secondary Schools: A Review of The Research. Rev Educ Res 1996; 66(4): 459-506. [http://dx.doi.org/10.3102/00346543066004459]

[14] Jones B, Kmitta D. Looking for Success: Evaluating Peer Mediation and Conflict Resolution Education Program.1999. A Workshop for the Ohio Commission for Dispute Resolution.

[15] Thompson NE. The impact of conflict resolution education on participating students and their families: A qualitative case study .

[16] Hay I, Byrne M, Butler C. Evaluation of a conflict-resolution and problem-solving programme to enhance adolescents' self-concept. Br J Guid Counc 2000; 28(1): 101-13. [http://dx.doi.org/10.1080/030698800109646]

[17] UNESCO Principal Office for the Asia-Pacific Region Bangkok and the University of Education Indonesia. Learning to Live Together in Peace and Harmony: Value Education for Peace, Human Rights, Democracy and Sustainable Development for the Asia-Pacific Region. In: UNESCO-APNIEVE Source Book for Teacher Education and Higher Education Level. Bandung: Universitas Pendidikan Indonesia 2000.

[18] Sheldon KM, Kasser T. Coherence and congruence: Two aspects of personality integration. J Pers Soc Psychol 1995; 68(3): 531-43. [http://dx.doi.org/10.1037/0022-3514.68.3.531] [PMID: 7714728]

[19] Alexandria VA. ASCA national standards for students one vision, one voice American School Counselor Association (ASCA) 2004. Available at: http://www.achievetexas.org/uploads/5/2/9/2/52920981/asca_national_standards_for_students.pdf

[20] Anderson R. A definition of peace. Peace Conflict 2004; 10(2): 101. [http://dx.doi.org/10.1207/s15327949pac1002_2]

[21] July Reynolds, Ruth Peaceful Pedagogy, Teaching Human Rights Through the Curriculum. Newcastle University 2010.

[22] McEvoy-Levy S. Youth as social and political agents: Issues in post-settlement peace building: Kroc Institute of Peace Studies. San Diego, Calif: Occasional paper no. 21. 2001.

[23] Aryani F. Peace Education and Human Rights Model to Prevent School Violence Makassar: Research Center, Makassar State University 2009. Available at: http://digilib.unm.ac.id/gdl.php?mod=browseop=readid=unm-digilib-unm-faridaarya-301

[24] Kartadinata S. Model Layanan Pedagogis Serta Bimbingan Dan Konseling Untuk Pengembangan Mindset Kultur Kedamaian . Bandung: LPPM Universitas Pendidikan Indonesia: Laporan penelitian 2013.

[25] Alwasilah AC. Etnopedagogi. Bandung: Kiblat Buku Utama Publisher. 2009.

[26] Wells LC. A culture of teaching peace. UNESCO Conference on Intercultural Education Finland 2003; 16 : 1-46.

[27] Borders A, Anne L D, Drury S M. Comprehensive School Counseling Programs: A Review for Policymakers and Practitioners. J Couns Dev 1992; 70: 487-95. [http://dx.doi.org/10.1002/j.1556-6676.1992.tb01643.x]

[28] Fountain S. Peace education/conflict resolution evaluation methods: UNICEF New York 1998. (unpublished paper, available from the author).

[29] Kartadinata S. Peace Pedagogy. Bandung: Pikiran Rakyat, Wednesday Edition: 2013; pp 26.

\section{(C) 2017 Setiadi et al.}

This is an open access article distributed under the terms of the Creative Commons Attribution 4.0 International Public License (CC-BY 4.0), a copy of which is available at: (https://creativecommons.org/licenses/by/4.0/legalcode). This license permits unrestricted use, distribution, and reproduction in any medium, provided the original author and source are credited. 